\title{
TRANSFORMATION VARIABLES IN HIGHER EDUCATION: A SYSTEMATIC LITERATURE REVIEW
}

\author{
Yasni Nurul Huda Mohd Yassin', \\ Thahira Bibi TKM Thangal', \\ Mohd Sharial Bungsu', \\ Mohd Hassan Mohd Osman", \\ Akmal Aini Othman', \\ Azianti Ismail ${ }^{6 i}$ \\ ${ }^{1}$ Faculty of Business and Management, \\ Universiti Teknologi MARA Shah Alam, \\ Selangor, Malaysia \\ ${ }^{2}$ Faculty of Business and Management, \\ Universiti Teknologi MARA Cawangan Johor, \\ Kampus Pasir Gudang, \\ Johor, Malaysia \\ ${ }^{3}$ Azman Hashim International Business School, \\ Universiti Teknologi Malaysia, \\ Johor, Malaysia \\ ${ }^{4}$ School of Graduate Studies, \\ UNITAR International University, \\ Selangor, Malaysia \\ ${ }^{5}$ Faculty of Business and Management, \\ Universiti Teknologi MARA Cawangan Johor, \\ Kampus Segamat, \\ Johor, Malaysia \\ ${ }^{6}$ Faculty of Mechanical Engineering, \\ Universiti Teknologi MARA Cawangan Johor, \\ Kampus Pasir Gudang, \\ Johor, Malaysia
}

\begin{abstract}
:
The higher education sector faced increasingly tense to transform due to the digitization that reshapes the world in the $21^{\text {st }}$ century to strengthen and improve the teaching and learning environment. The present critical success factors driven by global-profit-making reform institutions are affected by both external and internal issues. This systematic article review expounds on the instrumental transformation variables that influence higher education institutions globally. The exploration of these variables is not a new phenomenon in this research field and has long gained numerous scholars' attention.
\end{abstract}

\footnotetext{
i Correspondence: email yasni@utm.my, thahira881@uitm.edu.my, mohdsharial@utm.my,
} mohd.hassan@unitar.my, akmal123@uitm.edu.my, azianti106@uitm.edu.my 
However, most of these past inquiries overlooked the effects of cultural and contextual components, where the higher education landscape perspectives are often underrepresented. Hence, this study aims to fill this gap by critically reviewing a considerable amount of past studies on the changes in Asian educational institutions. The Systematic Review approach was adopted for data analysis, accessing main journal databases and search engines through Elsevier, ResearchGate, Google Scholar, ScienceDirect, Web of Science, Scopus, Emerald and EBSCO. The search efforts resulted in a corpus of $\mathbf{3 3}$ articles were reviewed. As a result of the thematic analyses, eight main themes were formulated namely, Globalization, Income Generation and Financial Implication, Institutional Policies, Knowledge Management, Learning Innovation, Governance in Institutional Restructuring, Synergy, and Leadership as dominant variables for the higher education sector. Several recommendations were also presented for the reference of relevant parties and future scholars.

Keywords: transformation, higher learning/education institution, systematic review

\section{Introduction}

Institutional transformation is seen as an approach to strengthen the independence and managing changes in both the governance and the management of institutions (Wright \& Ørberg, 2015). The governance of an institution involves the structures and processes of decision-making, whereas the management of an institution entails the implementation of these decisions. The decision-making process and its implementation may require the creation of new structures, specific allocation resources criteria for activities, allotment of tasks to different groups, and effective evaluations of performance. In this case, structures often refer to offices, positions, and formal roles within an organization while criteria include the basis for distribution of responsibilities and resources to all lower-level units within an organization. According to Mader et al., (2013), change management, leadership, support, and governance are pertinent factors in maintaining the sustainability of an institution. Studies by Azman et al. (2016), Balas et al. (2008), Cano (2017) and Loh \& Mohd Yusof (2018) presented consistent findings where leadership, staff buy-in, operations, incentives structure and empowerment are some key factors affecting transformational success in higher institutions. Azman et al. (2016) also mentioned that transformation comes with designated institutional policies alongside financial investments. On the other hand, Shariffuddin et al. (2017) listed globalization, internationalization, world-class rankings, government policies, corporatization and privatization, governance, academic career, and academic activities as catalysts of change in Malaysian higher institutions. It also focuses on refining the skills and capabilities of human capital in building capacity for economic and social expansion (Burnes \& Jackson, 2011; Maassen et al., 2017). These are the additional challenges that leaders need to address which are mass drivers of performance and sustainability. 
The process of transformation has exerted a considerable impact on the overall institutional functions and various groups within the university's organization. Experts claimed that the restructuring process has, to a certain extent, altered the university's mission, whereas others feel that there the reformation of the system was a final resort. Strong instances of resistance to these changes and the restructuring process are common in many countries. The continuous process of bargaining and negotiating is significant in the restructuring effort where certain universities have been more successful than others in their implementation of change. Therefore, there is a need to investigate the key institutional factors in enabling successful transformations of the higher education landscape. Hence, this systematic review of articles focuses on these transformational factors from the perspectives of Asian educational institutions. This observation in literature collected from scientific research leads to the conclusion that higher institutions emphasize different factors that determined the success of the reform process. Therefore, this study is to explore potential indicators for a better understanding to address the question: What are the pertinent factors that enable effective and successful reform process in the higher education perspective?

\section{Methodology}

This research consists of a systematic literature review (SLR) process which approach is strengthened via a more transparent article retrieving process, a wider area of prominent research with more significant objectives that can control research bias (Andy Siddaway, 2014; Kitchenham \& Ebse, 2007; Okoli, 2015; Tasdemir \& Gazo, 2018). Apart from that, this approach also seemingly motivates the researcher to produce quality evidence with more significant results (Mallett et al., 2012).

The response to the evolution and innovation in the pedagogy of academic research and knowledge-based economy has caused remarkable changes in the traits and functions of higher education institutions around the world. Higher education has become a prominent agenda in improving the global socio-economic status and the delivery of quality development.

Institutional transformation involves the process of an organization shifting its business model to a desired future state, and obviously is a long term and continuous process (Kotter, 1995). Brown (2017) mentioned that managing change is the collision of thoughtful development with unintended consequences where he puts forth "Without productively engaging people, successful change is impossible". He also stated that if a change does not prompt better logical and emotional sense, perhaps the change should not be implemented. Propelled by the driving force of technology and globalization, the economic landscape continuously transforms in a way that undermines the relevance of how a firm should be managed and what underlies its success (Prastacos et al., 2002). In this new millennium, it is more challenging for an organization to sustain its competency or even survive in a diverse market. When an organization is threatened by 
environmental changes such as crisis or competition, it is apparent that there is a need for effective communication as technology develops and higher customer demands are made. Institutional transformation is not an option as it is a fundamental necessity in succeeding within the new competitive landscape (Hamel \& Prahalad, 1996). Institutions need to evaluate its performance by reviewing its business strategies, corporate structure, operational process, and human capital policies to identify areas that are in need of constant transformation. These changes have to be implemented accordingly to maintain its competitive advantages. While education has been regarded as the asset for improvising teaching and learning agenda (Lee, 2002), organizational culture assist institutions to transform and develop for the better (Mzangwa, 2019).

Real transformation begins from the heart of the organizational team. The collaborative intent to focus on any shortcomings and to exceed organizational expectations, produce highly exceptional results. Previous literature from other industries including manufacturing and healthcare concluded that numerous factors can influence the transformational success in an organization. The internal factors affecting organizational transformation are identified as - the vision and mission of the institution, income generation/financial management, organizational culture, institutional governance and autonomy, networking and synergy, integrated system and technological development, research and innovation, leadership/talent management, decision making and communication. On the other hand, the external factors that affect the strategic initiatives of an organization as a whole comprised of economical changes, political changes, globalization/internationalization, knowledge management, and social culture. This comparison is important to identify whether the internal or external factors have a greater impact on higher education transformation, allowing institutions to implement effective measures in sustaining global competition. To date, investigations were focused on the transformational relationship involving the aforementioned factors. However, the best referred practices concerning the major indicators in Asian higher education perspective remains limited.

\section{Materials and Methods}

This section explains the three sub-sections of the methodology namely, the systematic review process, the data abstraction process and the data analysis process in the current research. This is a qualitative multiple case study approach highlighting particularly higher education institutions around the world. Data were collected from many sources and analysed using Nvivo12.

\subsection{The Systematic Review Process for Article Selection}

\subsubsection{Identification of Articles}

The systematic review process in identifying relevant articles for the present study comprised of three main stages (Shaffril et al., 2020). The first stage is where keywords 
are identified and through the process, the researcher managed to generate twelve themes and keywords related to the factors contributing to transformation success. This was then followed by the process of searching for related and similar terms based on thesaurus, dictionaries, encyclopaedia, and past researches. Accordingly, search strings on ResearchGate, Google Scholar, ScienceDirect, Web of Science, Scopus, Elsevier, Emerald, and EBSCO for the search engine and database search and Mendeley reference manager was included and databases were developed (refer to Table 1) after all keywords were determined. The search process managed to successfully retrieve a total of 428 articles from all databases based on similar keywords and themes. Hence, in total, 428 articles were retrieved in the first stage of the systematic review process.

Table 1: The Search String

\begin{tabular}{|l|l|}
\hline Database Search String & \\
\hline WoS & $\begin{array}{l}\text { TS=("transformation" OR "change*management" OR "reformation" AND } \\
\text { (higher education)) }\end{array}$ \\
\hline Scopus & $\begin{array}{l}\text { TITLE-ABS-KEY(("transformation") OR ("change*management") OR } \\
\text { ("reformation") AND (higher education)) }\end{array}$ \\
\hline $\begin{array}{l}\text { Others (Scholar, Elsevier, } \\
\text { Emerald) }\end{array}$ & $\begin{array}{l}\text { ("transformation") OR ("change*management") OR ("reformation") AND } \\
\text { (higher education) AND (factors) AND (Challenge) }\end{array}$ \\
\hline
\end{tabular}

\subsubsection{Screening}

The purpose of screening materials from the first stage was to remove duplicating and unrelated articles. In this case, a total of 368 articles from the first stage were excluded. It was decided that only journal (research articles) were to be analysed while book chapters and conference proceedings were excluded from the current research. It is crucial to note that a 14-year (2005 - 2019) timeline was chosen for the purpose of this study. Studies conducted globally were also selected as comparative bases as they are in line with the objective of this review. The journal articles were shortlisted based on the selection criteria (Refer to Table 2).

Table 2: The Inclusion and Exclusion Criteria

\begin{tabular}{|l|l|l|}
\hline Criterion & Eligibility & Exclusion \\
\hline $\begin{array}{l}\text { Literature } \\
\text { type }\end{array}$ & $\begin{array}{l}\text { Journal (research } \\
\text { articles) }\end{array}$ & $\begin{array}{l}\text { Journals (review), book series, book, chapter in a book, } \\
\text { conference proceeding }\end{array}$ \\
\hline Language & English & Non-English \\
\hline Timeline & Between 2005 and 2019 & $<2004$ \\
\hline
\end{tabular}

\subsubsection{Eligibility}

A total of 47 articles were prepared for the third stage of the review: the eligibility stage. At this stage, the titles, abstracts, and the main contents of all the articles were carefully examined to ensure that they fulfilled the inclusion criteria and are suitable for achieving the objectives of the current research. Consequently, a total of 33 remaining articles with empirical methodology were selected for analysis (See Figure 1). 


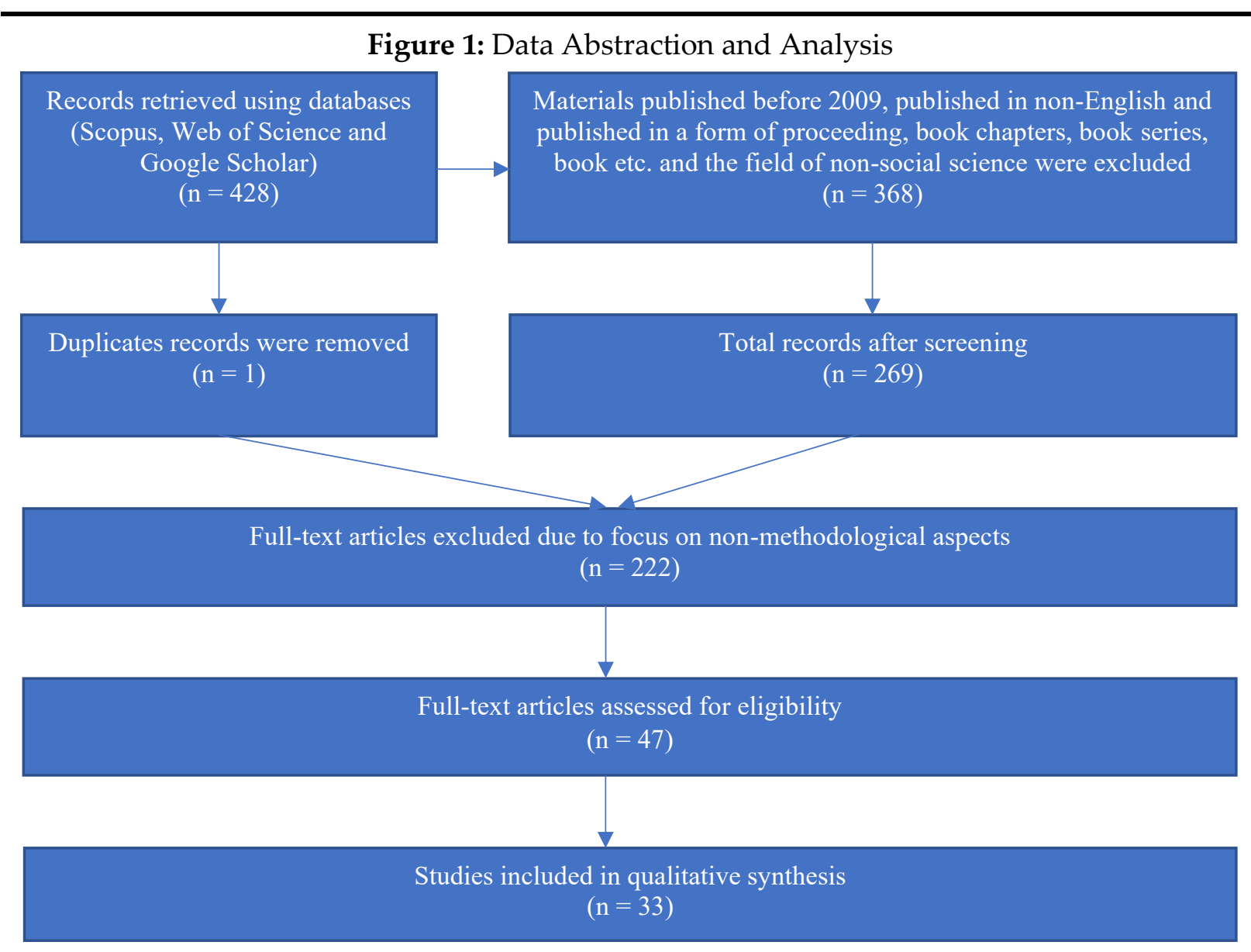

\subsubsection{Data Abstraction and Analysis}

This study utilized the integrative review technique, which analyses and synthesizes diverse research designs simultaneously (qualitative, quantitative and mixed methods), hence, reviews can be conducted systematically and rigorously (Whittemore R. and Knafl K., 2005).

The process involves tagging materials into appropriate themes based on thematic analysis. Forty-seven eligible articles were examined and after a thorough assessment, a total of twelve (12) themes were derived for the analysis. However, for this study objective, only eight (8) main themes namely Globalization, Income Generation and Financial Implication, Institutional Policies, Knowledge Management and Learning Innovation, Governance in Institutional Restructuring, Synergy, Culture, and Leadership will be further finalized as the most pertinent success factors for Malaysia higher education. These themes were discussed and developed as the results of the study.

\section{Results and Discussion}

Twelve themes related to the transformation elements that incorporate previous research points of view from several countries and from other sectors such as manufacturing and healthcare between 2001 to 2017 appeared to be similar to the scenario of Malaysian 
higher institution's landscape. The summaries of the major findings are further elaborated in Table 3.

Table 3: Identification of theme sources

\begin{tabular}{|c|c|c|}
\hline \# & Themes & Sources \\
\hline 1 & Globalization & Apple 2001; Meredith 2008; Rees- Stroud 2001; Lee 2005 \\
\hline 2 & $\begin{array}{l}\text { Income Generation } \\
\text { and Financial Implication }\end{array}$ & $\begin{array}{l}\text { Sara 2017; Bjorn 2012; Timothy Church et al., 2003, Ahmad et al. } \\
2007\end{array}$ \\
\hline 3 & Institutional Policies & Sara 2017 \\
\hline 4 & $\begin{array}{l}\text { Knowledge Management } \\
\text { and Learning Innovation }\end{array}$ & Sara 2017; Bloom 2016; Sedgwig 2005 \\
\hline 5 & $\begin{array}{l}\text { Governance in } \\
\text { Institutional Restructuring }\end{array}$ & $\begin{array}{l}\text { Sara 2017; Bloom 2016; Timothy Church et al., 2003; Mader } 2013 \text {, } \\
\text { Ahmad et al. } 2007\end{array}$ \\
\hline 6 & Synergy & Meredith 2008; Marklein 2016 \\
\hline 7 & Leadership & $\begin{array}{l}\text { (Achanga et al., 2006; Agili \& Okibo, 2015; Ahmad et al., 2013; } \\
\text { Balzer et al., 2015; Cano et al., 2014; Duong, 2015; Emiliani \& Stec, } \\
\text { 2005; Event \& Paper, 2010; Ferrer-Balas et al., 2008; Hines \& } \\
\text { Lethbridge, 2008; Leithwood et al., 2004; Liker, 2004; Litalien et al., } \\
\text { 2009; Lussier, 2009; Mader et al., 2013; Radnor, 2010; Scherrer- } \\
\text { Rathje et al., 2009; Timothy Church et al., 2003) }\end{array}$ \\
\hline 8 & Research & Sara 2017; Sara 2017 \\
\hline 9 & $\begin{array}{l}\text { Information and } \\
\text { Communication } \\
\text { Technology }\end{array}$ & $\begin{array}{l}\text { Bloom 2016; Inzelt 2004; Francis 2003; Ragsdale-Harrington 2004, } \\
\text { Ahmad et al. } 2007\end{array}$ \\
\hline 10 & Decision Making & Bjorn 2012 \\
\hline 11 & Communication & Bjorn 2012 \\
\hline 12 & Culture & Agili 2015, Ahmad et al. 2007 \\
\hline
\end{tabular}

Eight (8) most pertinent factors from thirty-three (33) studies are considered viable to determine the transformation success in the higher education sector as were highlighted by most authors in most continents. Findings also found that the least researched factors were institutional policies, communication, decision making, and culture in regards to higher education perspective, but were considered as the most at the manufacturing and healthcare sector. Figure 2 shows how authors arrived at the concluded themes while the discussion on the eight most pertinent factors for the higher education perspective was elaborated thereafter. 
Figure 2: Themes Eligibility

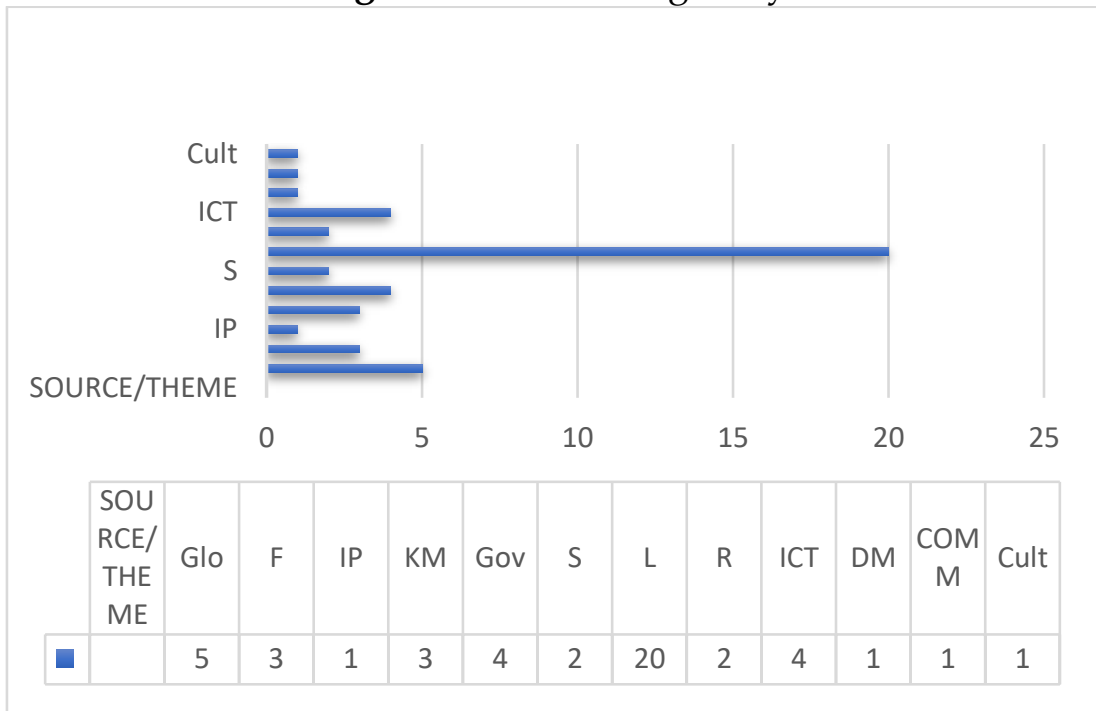

Most studies (Church et al., 2003; Hines et al., 2004; Liker, 2004; Leithwood 2004; Lussier 2005; Achanga et al., 2006; Steele 2007; Antony 2007; Cano 2008; Balas et al. 2008; Naslund 2008; Scherrer-Rathje et al., 2009) Williams, 2009; Balzer, 2010; Liberia, 2010; Emiliani, 2012; Antony et al., 2012; Radnor and Osborn, 2013; Antony, 2014; Balzer et al., 2015; Agili, 2015; Duong, 2015; Mader, 2013) agreed that successful implementation requires the commitment of top management. In this study, commitment of top management is translated as the leadership quality which is the heart issue in any organization and mostly considered in research. Liker (2004, p.306) quoted that "if the top is not driving the transformation, it will not happen". Mader (2013), Cano (2008), Williams (2009) claimed that the basis of leadership is required in the historical and present development of a university. Leadership may also be a driving force when the leader sees transformation as a method of passing on his/her legacy to the organisation (Ferrer-Balas et al., 2008; Mader, Scott, \& Abdul Razak, 2013). This statement is supported by Elliott \& Goh (2013) stating that leadership is the most pervasive influence on organizational learning effects.

At the organization level, management leaders are deemed as change specialists where they are responsible of effectively actualizing the change. Leadership role is important in designing the university's policies which are the core values of an organization that determines the direction of the university as mentioned by Sara 2017. In an industrial context, the university can also be classified as a business entity whereby, students are considered as prospects for businesses. As stated by Leithwood et al. (2004), the reformation of educational institution success factors is dependent on the motivations and capacities of leadership in universities/ schools. Having a motivated team of educators and a management team with high leadership qualities, the university will be bound to possess clear objectives and purpose on what is required for success. Leithwood et al. (2004) also added that leadership in the education system is robust in setting up a clear course or program to enable a better understanding of those in the academic system 
and clear pathways will also assist lecturers in designing course outlines which match the pedagogical objectives and are aligned to the university policies and industrial needs. Moreover, leadership in the university administration is also important to establish the standards of key performance index besides assisting the administration in tracking the progress and performance of the education system (Leithwood, K. et al., 2004). Lussier (2005) added that leaders must also be able to develop a support system in the organization. In the education system, strong support from the management is a reflection of the leadership capacity in the sector. Leaders should be able to provide support to the academicians in performing their job to the best of their ability. Sufficient resources and support are necessary for the workforce to enhance their creativity and motivation. Leaders should ensure that the organization works within the range of conditions and incentives that fully support rather than inhibit the process of teaching and learning.

The organization's vision and mission need to be aligned to the organization's objectives to enable the strategic enhancement of its role in educating and producing skilled workers for the professional labour market. Apple (2001) claimed that globalization has influenced cultural institutions, the global economy as well as political systems. Thus, education is seen as a strong competitive platform in many societies. According to Meredith \& Burkle (2008), globalization has become the backbone in enabling institutions to perform more efficiently.

The forces of globalization have driven nations to initiate policy reforms in order to ensure the excellence, relevance and marketability of the higher education system while the local ethnic polarizations work in diagonally opposite directions by demanding equal opportunities, access and treatment. Walford et al. (2002) describe this evolving scenario in higher education as "the social transformation that has entailed a fundamental restructuring of the organization of higher education itself". According to Lee (2005), the essence of the restructuring process is a redefinition of the relationship between the university, the state, and the market, and a drastic reduction of institutional autonomy. The restructuring of higher education is happening in many countries through cultural diffusion and institutional isomorphism. However, this does not mean that all higher education systems are uniform in these changes since there are varied responses to these globalisation forces depending on the politics, economy, culture, and the structural features of the particular education system. Campbell (2018) also mentioned that globalization had become an effective weapon for the higher education transformation process.

\subsection{Income Generation and Financial Implication}

The financial implications of the expansion of higher education have always been managed by governments through a substantial reduction in public funding for each student, requiring these institutions to reshape their internal organization and practices. To be a university student or a member of the staff involves constant changes within the 
working environment. The impacts of the substitution of student grants with loans and the more recent introduction of fees for undergraduates have further transformed student's experience of higher education. Currently, higher education institutions are becoming more dependent on their entrepreneurial capacity for revenue through student enrolments and research grants, commercialization of product contracts as well as endowments. In other words, the constraints of financial means available for postsecondary education gave rise to the privatization of higher education (Slaughter 1998; Carnoy 2000).

Higher education contributes to improved national income through diverse channels. To begin with, the labour force participation rates among degree holders are significantly higher than those who are less educated. An equally important fact is that unemployment rates are lower among university graduates than secondary school graduates. This factor certainly increases the demand for higher education since the opportunity cost of seeking higher education does not seem too much when compared to the level of unemployment among secondary school graduates. Thus, enrolling in tertiary education is deemed to be less costly and is a way of reducing unemployment chances. Higher educated talents are generally paid more, leading to an increased average income among those with education. The capacity building and knowledgedriven production of goods and services in the labour market also increase the demand for more educated manpower equipped with the skills of the century.

\subsection{Knowledge Management and Learning Innovation}

The concept of e-learning has taken off as a lens through which to study put innovation for teaching and learning on technology-enhanced learning (TEL) in higher education. Technological learning plays an important role in firms' competitive success, supporting their ability to develop maintain and exploit dynamic core competencies, besides leveraging firms to pursue technology-based strategies (Kocoglu et al., 2012; Rathi et al., 2016). Knowledge is becoming an increasingly popular commodity between nations. The growth of the knowledge-based economy and the state of globalisation has induced competition among employers and institutions worldwide for the best brains. Several economic and social factors encourage international student mobility and competition between countries for foreign students (Clark and Sedgwick, 2005, OECD 2004a), encouraging the traditional form of cross-border flow in higher education involves the migration of students from one country to another to advance their studies.

The Malaysian private higher education sector has been attempting to adopt the higher education system of developed nations since the mid-1990. Through this adaptation, numerous international campuses have been set up to cater for a vast majority of local and international students. Malaysia is currently viewed as an educational hub by foreign partners who are keen to work towards a mutual solution for both parties. In addition to investing new faculty positions and launching targeted fundraising activities, a prominent response to knowledge change at the local campus level is 
to alter the academic structure by constantly updating the selection of courses, degree programs, and departments. While knowledge change in higher education is often viewed as an inertia or expansion, higher education professionals understand the threat of selective consolidation and program elimination in terms of insufficient centrality, quality or cost-effectiveness (Bailey et al., 2003).

\subsection{Management Changes}

Human habits and satisfaction with their current performance, status and situation will initially create resistance to change (Mainardes et al., 2011). Compliant behaviours do not assist in making institutional change initiatives successful. Thus, the improvement of managerial productivity is central to institutional restructuring as many institutions could not afford to manage change. Management changes is often due to the advancement of technology, change in production techniques, change in customers and stakeholders behaviour, economic changes, as well as business activities that force institutions to initiate change for sustainability (Thakur \& Mangla, 2019). Most beneficial management change can be realised through organization structure, organization employees, specific business technology, production techniques and administration restructuring (Hamraz et al., 2013; Hashim, 2017).

\subsection{Governance in Institutional Restructuring}

Institutional restructuring is defined as changes in both governance and management of institutions. Governance involves structures and forms of decision-making, while administrations carry out the implementation of decisions. Lee (2002) mentioned that institutional restructuring is related to performance, control of the institution, and decision making, thus providing specific structures for direction in fulfilling the expectation and obligation of the institution. On the other hand, Cadbury Report (1992) defined governance as a framework in which an organization is directed and control. Shariffuddin et al. (2017) indicates the keys to successful transformation are governance, academics career and academic activities involving various types of HEIs, academics' identity leadership supports and strategies. Varghese \& Martin (2013) mentioned that new governance model is recommended wherein the University leaders needs to be given autonomy in decision-making and finances to focus more on funding and the branding of university, plays the role of the custodian of academics, research and students to sustain its performance and operation.

\subsection{Synergy}

Synergising all activities and continuous initiatives between the alliance of higher learning institutions, community engagement, industries, intelligent strategic partners are some of the influencing variables in the corporate governance essence. Various rankings consider combinations of measures of funding and endowment, research excellence and/or influence, specialization expertise, admissions, student options, award 
numbers, internationalization, graduate employment, industrial linkage, historical reputation and other criteria and mostly evaluating institutional research output. Meredith \& Burkle (2008) mentioned that the strategy of the organization needs to be constantly reviewed to maximize network synergy.

\section{Discussion}

From the thematic analysis conducted, it was founded that most pertinent indicators that reflect higher education success in transformation is leadership factors. 20 out of 33 studies (60.61\%) indicates that leadership the most important components in the transformation process for most higher education institutions. The emergence of higher learning institution as influential factors in talent development is the main agenda in the national development plans of most countries including Malaysia (Morsidi, 2009). Most authors (Achanga et al., 2006; Agili \& Okibo, 2015; Ahmad et al., 2013; Balzer et al., 2015; Cano et al., 2014; Duong, 2015; Emiliani \& Stec, 2005; Event \& Paper, 2010; Ferrer-Balas et al., 2008; Hines \& Lethbridge, 2008; Leithwood et al., 2004; Liker, 2004; Litalien et al., 2009; Lussier, 2009; Mader et al., 2013; Radnor, 2010; Scherrer-Rathje et al., 2009; Timothy Church et al., 2003) mentioned that leadership factor is the core importance of all major industries including higher education which is highly required to transform the countries into a developed nation. Consequently, the higher education system has undergone multiple rounds of transformations- embarked on a structural transformation of its economy with the agenda of human capital development taking the center stage in the transformation agendas.

Undoubtedly, the management of higher education institutions may encounter some difficulties in handling transformation. In addition to a difficult political climate and diminished public confidence, financial constraints loom largely alongside the pressure of alternative structural and resource commitments in various knowledge areas. Deliberations over academic restructuring and resource reallocation may seem endless often bogged down by inadequate processes which lack substance and likely consequences of proposed changes. The unprecedented public scrutiny of the academic enterprise exacerbates tensions on campus between proponents of different academic areas, between those responsible for planning and those responsible for safeguarding faculty governance, as well as between those who advocate compliance with external demands for demonstrated accountability and those who argue for resistance.

The intermingling of academic considerations with wider economic and political concerns suggests that deliberations over the reorganization of academic units are most likely to be ongoing. At the same time, little is known about the consequences of structural and material resource shifts in academic areas, for students and the society at large. Moreover, it is uncertain whether any shared sense of institutional purpose, the basis for interdependence on campuses and the core academic activities of knowledge creation, preservation, and transmission will remain viable. 


\section{Conclusion}

It can be concluded that from this research, leadership factors emerged as an overarching theme and was being critical to ensuring the success of the overall initiative of transformation in Higher Education in reality. However, there is little research to substantiate this claim that human factor is the major constraint to this transformation agenda in the higher education perspective. Nonetheless, the result can be further explored to perform a comprehensive study that needs future work including the investigation of the interaction and relationship between these themes as well as expanding on the current knowledge.

\section{Conflict of Interest Statement}

The authors declare no conflicts of interests.

\section{About the Authors}

Yasni Nurul Huda Mohd Yassin has more than 20 years of experience in academic matters, administration and management with a corporate background. Her research interest involves leadership, lean management, sustainability, and change management theories.

Thahira Bibi TKM Thangal is a senior lecturer at the Faculty of Business Management UiTM Johor has 13 years of teaching experience with a legit industrial background. Her research interests include Human Resource Management, Entrepreneurial Behavior, Women Empowerment and Marketing.

Mohd Sharial Bungsu has the experience of teaching at the university for 2 years and with experiences as researcher in many departments. His research interests include sociology of governance, nationhood studies, ethnic relations, social cohesion and unity and qualitative studies.

Mohd Hassan is a Professor and currently is the Dean of Graduate Studies UNITAR International University with more than 30 years of teaching experience. He was the former Deputy Vice Chancellor (Academic \& International) at UMK and Dean of International Business School UTM for several years.

Akmal Aini is an Associate Professor at the Department of Management \& Marketing, Faculty of Business Management UiTM Johor with more than 10 years of teaching experience. Her research interests are in the areas of Supply Chain Management, Construction Procurement, Relationship Marketing and Channel Management.

Azianti Ismail is an Associate Professor at the Faculty of Mechanical Engineering UiTM Johor with more than 10 years of teaching experience. Her research interests favor towards diverse areas of research in Outcome Based Education, Design for Reliability, Lean Manufacturing System and DOE. 


\section{References}

Achanga, P., Shehab, E., Roy, R., \& Nelder, G. (2006). Critical Success Factors For Lean Implementation Within Smes. Journal Of Manufacturing Technology Management, 17(4), 460-471. https://doi.org/10.1108/17410380610662889

Agili, J., \& Okibo, W. (2015). Factors Influencing Implementation Of Change In Selected Public Universities In Kenya. International Journal Of Economics, Commerce And Management, III(5), 1201-1217.

Ahmad, A. R., Farley, A., \& Kim-Soon, N. (2013). Funding Reforms In Malaysian Public Universities: Transitions Towards Competitive Funding. Australian Journal Of Basic And Applied Sciences, 7(10), 553-561.

Andy Siddaway. (2014). What Is A Systematic Literature Review And How Do I Do One? (Issue 1, Pp. 1-13).

Apple, M. W. (2001). Markets, Standards, Teaching, And Teacher Education. Journal Of Teacher Education, 52(3), 182-196. https://doi.org/10.1177/0022487101052003002

Bailey, T., Badway, N., \& Gumport, P. J. (2003). For-Profit Higher Education And Community Colleges. Educational Research, X, 1-69.

Balzer, W. K., Brodke, M. H., \& Kizhakethalackal, E. T. (2015). Lean Higher Education: Successes, Challenges, And Realizing Potential. International Journal Of Quality And Reliability Management, 32(9), 924-933. https://doi.org/10.1108/IJQRM-08-2014-0119

Brown, R. A. (2017). The HST Model For Change: Enchancing The People Side Of Organizational Development. Denro Classics.

Burnes, B., \& Jackson, P. (2011). Success And Failure In Organizational Change : An Exploration Of The Role Of Values Success And Failure In Organizational Change : An Exploration Of The Role Of Values. Journal Of Change Management, 11(2), 13316241. https://doi.org/10.1080/14697017.2010.524655

Campbell, J. (2018). The Trilemma Of Malaysian Higher Education. 17(1), 3-24. https://doi.org/10.1386/Tmsd.17.1.3

Cano, M., O'Reilly, E., \& Kourouklis, A. (2014). Lean Second Time Around: Lessons Learned For Higher Education. Liverpool (2014): 17th Toulon-Verona Conference "Excellence In Services," 0(0), 43-50.

http://www.toulonveronaconf.eu/Papers/Index.Php/17tvc/Article/View/117

Colombi, John M.; Miller, Michael E.; Schneider, Michael; Mcgrogan, Jason; Long, David S.; Plaga, J. (2012). Model Based Systems Engineering With Department Of Defense Architectural Framework. Systems Engineering, 14(3), 305-326. https://doi.org/10.1002/Sys

Duong, T. V. A. (2015). Leadership And Curriculum Reform In Higher Education Institutions : A Case Study Of A Vietnamese University. In Thesis (Vol. 13, Issue 3). Elliott, C. J., \& Goh, S. C. (2013). Does Accreditation Promote Organizational Learning? A Multiple Case Study Of Canadian University Business Schools. Journal Of Management Development, 32(7), 737-755. https://doi.org/10.1108/JMD-03-2011-0028 
Emiliani, M. L., \& Stec, D. J. (2005). Leaders Lost In Transformation. Leadership And Organization Development Journal, 26(5), 370-387.

https://doi.org/10.1108/01437730510607862

Event, G., \& Paper, W. (2010). Leadership And Change In Post - Conflict States : A Case Study Of Liberia. East, 1-31.

Ferrer-Balas, D., Adachi, J., Banas, S., Davidson, C. I., Hoshikoshi, A., Mishra, A., Motodoa, Y., Onga, M., \& Ostwald, M. (2008). An International Comparative Analysis Of Sustainability Transformation Across Seven Universities. International Journal Of Sustainability In Higher Education. https://doi.org/10.1108/14676370810885907

Hamel, G., \& Prahalad, C. K. (1996). Competing In The New Economy: Managing Out Of Bounds. In Strategic Management Journal (Vol. 17, Issue 3, Pp. 237-242). Https://doi.org/10.1002/(SICI)1097-0266(199603)17:3<237::AID-SMJ829>3.0.CO;2-G

Hashim, M. (2017). Change Management. July 2013. Https://Doi.Org/10.6007/IJARBSS/V3I7/92

Hines, P., \& Lethbridge, S. (2008). New Development: Creating A Lean University. Public Money And Management, 28(1), 53-56. https://doi.org/10.1111/J.14679302.2008.00619.X

Kitchenham, B., \& Charters, S. (2007). Guidelines For Performing Systematic Literature Reviews In SE. Guidelines For Performing Systematic Literature Reviews In SE, 1-44. https://userpages.uni-koblenz.de/\%7B \%7Dlaemmel/Esecourse/Slides/Slr.Pdf Kocoglu, I., Imamoglu, S. Z., Ince, H., \& Keskin, H. (2012). Learning, R\&D And Manufacturing Capabilities As Determinants Of Technological Learning: Enhancing Innovation And Firm Performance. Procedia - Social And Behavioral Sciences, 58, 842-852. https://doi.org/10.1016/J.Sbspro.2012.09.1062

Kotter, J. P. (1995). Leading Change: Why Transformation Efforts Fails. Harvard Business Review, 6(1), 9. https://doi.org/10.1016/0029-1021(73)90084-4

Lee, M. N. N. (2005). Restructuring Higher Education In Malaysia. 2004, 31-46. https://doi.org/10.1007/S10671-004-6034-Y

Leithwood, K. A., Louis, S. K., Anderson, S., \& Wahlstrom, K. (2004). How Leadership Influences Student Learning: A Review Of Research From The Learning For Leadership Project. The Wallace Foundation, January 2004, 1-90. https://doi.org/10.1007/978-90-481-2660-6

Liker, J. K. (2004). The Toyota Way 14 Management Principles From The World S Greatest Manufacturer.

Litalien, D., Guay, F., Geoffrion, S., Giguère, C.-É., Fortin, M., Fortin, C., Guay, S., Ducharme, F., Lévesque, L., Caron, C. D., Hanson, E., Magnusson, L., Nolan, J., Nolan, M., Manzo, G., St-Onge, S., Renaud, S., Guérin, G., Plard, M., ... Robette, N. (2009). No Titlel الابنز. Bifurcations, 45(1), 1-19. https://doi.org/10.7202/1016404ar Lussier, R. N. (2009). Human Relations In Organizations. Applications And Skills Building. 642. 
Maassen, P., Gornitzka, Å., \& Fumasoli, T. (2017). University Reform And Institutional Autonomy: A Framework For Analysing The Living Autonomy. Higher Education Quarterly, 71(3), 1-13.

Mader, C., Scott, G., \& Abdul Razak, D. (2013). Effective Change Management, Governance And Policy For Sustainability Transformation In Higher Education. Sustainability Accounting, Management And Policy Journal, 4(3), 264-284. https://doi.org/10.1108/SAMPJ-09-2013-0037

Mainardes, E. W., Alves, H., \& Raposo, M. (2011). The Process Of Change In University Management: From The "Ivory Tower" To Entrepreneurialism. Transylvanian Review Of Administrative Sciences, 33, 124-149.

Mallett, R., Hagen-Zanker, J., Slater, R., \& Duvendack, M. (2012). The Benefits And Challenges Of Using Systematic Reviews In International Development Research. Journal Of Development Effectiveness, 4(3), 445-455. https://doi.org/10.1080/19439342.2012.711342

Meredith, S., \& Burkle, M. (2008). Building Bridges Between University And Industry: Theory And Practice. Education And Training, 50(3), 199-215. https://doi.org/10.1108/00400910810873982

Mohamed Shaffril, H. A., Samsuddin, S. F., \& Abu Samah, A. (2020). The ABC Of Systematic Literature Review: The Basic Methodological Guidance For Beginners. Quality And Quantity, 0123456789. Https://Doi.Org/10.1007/S11135-020-01059-6

Mzangwa, S. T. (2019). Transformation As Part Of Evolving Organisational Culture In The South African Higher Education Institutions. Cogent Social Sciences, 5(1). https://doi.org/10.1080/23311886.2019.1638635

Okoli, C. (2015). A Guide To Conducting A Standalone Systematic Literature Review. Communications Of The Association For Information Systems, 37(1), 879-910. https://doi.org/10.17705/1cais.03743

Prastacos, G., Söderquist, K., Spanos, Y., \& Van Wassenhove, L. (2002). An Integrated Framework For Managing Change In The New Competitive Landscape. European Management Journal, 20(1), 55-71. https://doi.org/10.1016/S0263-2373(01)00114-1

Radnor, Z. (2010). Transferring Lean Into Government. Journal Of Manufacturing Technology Management, 21(3), 411-428. https://doi.org/10.1108/17410381011024368

Rathi, D., Given, L. M., Forcier, E., Rathi, D., Given, L. M., \& Forcier, E. (2016). Knowledge Needs In The Non-Profit Sector : An Evidence-Based Model Of Organizational Practices. https://doi.org/10.1108/JKM-12-2014-0512

Scherrer-Rathje, M., Boyle, T. A., \& Deflorin, P. (2009). Lean, Take Two! Reflections From The Second Attempt At Lean Implementation. Business Horizons, 52(1), 79-88. https://doi.org/10.1016/J.Bushor.2008.08.004

Shariffuddin, S., Razali, J., Raihan, W., Shaaidi, W., Safia, I., \& Ibrahim, A. (2017). Transformation Of Higher Education Institutions In Malaysia : A Review. February. Tasdemir, C., \& Gazo, R. (2018). A Systematic Literature Review For Better Understanding Of Lean Driven Sustainability. Sustainability (Switzerland), 10(7). 
https://doi.org/10.3390/Su10072544

Thakur, V., \& Mangla, S. K. (2019). Change Management For Sustainability: Evaluating The Role Of Human, Operational And Technological Factors In Leading Indian Firms In Home Appliances Sector. Journal Of Cleaner Production, 213, 847-862. https://doi.org/10.1016/J.Jclepro.2018.12.201

Timothy Church, A., Ortiz, F. A., Katigbak, M. S., Avdeyeva, T. V., Emerson, A. M., De Jesús Vargas Flores, J., \& Reyes, J. I. (2003). Measuring Individual And Cultural Differences In Implicit Trait Theories. Journal Of Personality And Social Psychology, 85(2), 332-347. https://doi.org/10.1037/0022-3514.85.2.332

Varghese, N. V., \& Martin, M. (2013). Governance Reforms And University Autonomy In Asia. In Policy Forum On The 'Design And Management Of Higher Education Systems: The Role Of Steering Policies And Governance Reforms In The Management Of Higher Education.' International Institute For Educational Planning (IIEP) 7-9 Rue Eugène Delacroix, 75116 Paris, France Info@Iiep.Unesco.Org www.iiep.unesco.org Cover.

Walford, G., Jephcote, M., Huddleston, P., Rees, G., Stroud, D., Daugherty, R., Mcculloch, G., Broadfoot, P., Tymms, P., Fitz-Gibbon, C., Dyson, A., Slee, R., Tomlinson, S., Arnot, M., David, M., Weiner, G., Robertson, S., \& Lauder, H. (2002). Education, Reform And The State. In Education, Reform And The State. https://doi.org/10.4324/9780203469552

Wright, S., \& Ørberg, J. W. (2015). Autonomy And Control: Danish University Reform In The Context Of Modern Governance. Learning Under Neoliberalism: Ethnographies Of Governance In Higher Education, 1(1), 178-200. 
Yasni Nurul Huda Mohd Yassin, Thahira Bibi TKM Thangal,

Mohd Sharial Bungsu, Mohd Hassan Mohd Osman, Akmal Aini Othman, Azianti Ismail

TRANSFORMATION VARIABLES IN HIGHER EDUCATION: A SYSTEMATIC LITERATURE REVIEW

Creative Commons licensing terms

Author(s) will retain the copyright of their published articles agreeing that a Creative Commons Attribution 4.0 International License (CC BY 4.0) terms will be applied to their work. Under the terms of this license, no permission is required from the author(s) or publisher for members of the community to copy, distribute, transmit or adapt the article content, providing a proper, prominent and unambiguous attribution to the authors in a manner that makes clear that the materials are being reused under permission of a Creative Commons License. Views, opinions and conclusions expressed in this research article are views, opinions and conclusions of the author(s). Open Access Publishing Group and European Journal of Education Studies shall not be responsible or answerable for any loss, damage or liability caused in relation to/arising out of conflicts of interest, copyright violations and inappropriate or inaccurate use of any kind content related or integrated into the research work. All the published works are meeting the Open Access Publishing requirements and can be freely accessed, shared, modified, distributed and used in educational, commercial and non-commercial purposes under a Creative Commons Attribution 4.0 International License (CC BY 4.0). 